УДК 338.43

DOI: $10.37734 / 2409-6873-2021-1-3$

\title{
УПРАВЛІННЯ ІННОВАЦІЙНО-ІНВЕСТИЦІЙНИМ ЗАБЕЗПЕЧЕННЯМ РОЗВИТКУ ПІДПРИЕМСТВ АГРАРНОГО СЕКТОРУ: ЗАГАЛЬНОДЕРЖАВНИЙ ТА РЕГІОНАЛЬНИЙ АСПЕКТ
}

\author{
I. А. МАЛИШ \\ аспірант кафедри маркетингу, підприємництва і організації виробництва, \\ Харківський національний аграрний університет імені В.В. Докучаєва
}

\begin{abstract}
Анотація. Мета статті полягає у висвітленні та узагальненні сучасних засад управління інноваційноінвестиційним забезпеченням розвитку підприємств аграрного сектору на загальнодержавному та регіональному рівнях. Методика дослідження. Вирішення поставлених у статті завдань здійснено за допомогою таких загальнонаукових і спеціальних методів дослідження, як діалектичний метод дослідження економічних процесів і явищ, систематизація та узагальнення наукових підходів до розв'язання проблеми, статистичне ранжування регіонів України за рівнем їх інноваційного потенціалу, а також методи аналізу та синтезу, порівняння, індукиії та дедукиї. Результати. Розроблено комплекс передумов для активізаиії інноваційно-інвестиційного розвитку аграрного сектору країни та запропоновано стратегічні важелі управління інноваційно-інвестиційним розвитком. Розроблено комплекс принцииів управління інноваційноінвестиційним розвитком регіону, таких як принципи масовості, результативності, адаптивності, інформаційної підтримки, фінансування, стимулювання. Практична значущість результатів дослідження. У статті обтрунтовано, щзо впровадження запропонованих вихідних передумов та стратегічних важелів управління дасть змогу сформувати гнучку та адаптивну модель інноваційно-інвестиційного розвитку конкретного регіону і буде сприяти високотехнологічному сучасному веденню сільського господарства на інновачійній основі.
\end{abstract}

Ключові слова: інноваційно-інвестиційний розвиток, управління інноваційно-інвестиційним розвитком, стратегічні напрями управління, принциипи управління інноваційно-інвестиційним розвитком, регіональний розвиток аграрного сектору.

Постановка проблеми в загальному вигляді та зв'язок із найважливішими науковими чи практичними завданнями. Інновації в сільському господарстві були б неможливими без відповідної системи управління інноваційно-інвестиційним розвитком. Саме управлінський аспект викликає найбільше спорів та складнощів, адже на всіх фазах розвитку інновації керівнику проєктом доводиться узгоджувати різноспрямовані інтереси учасників процесу впровадження. Інвестори, підприємство-новатор, розробник інновації та власник інтелектуальних прав на неї, акціонери, пайовики чи учасники товариства, держава в особі різних державних органів, банківська установа - ось неповний перелік осіб, що беруть участь у різних фазах та етапах інноваційноінвестиційного процесу. Таким чином, управління інноваційно-інвестиційним забезпеченням розвитку аграрних підприємств та пошук шляхів його удосконалення $\epsilon$ актуальним та потребує подальших наукових досліджень.

Аналіз останніх досліджень і публікацій. Проблеми управління інноваційним та інвестиційним розвитком аграрних підприємств висвітлені в працях В.О. Бойкова, Н.В. Чорної, М.Х. Корецького, Л.М. Васільєвої, О.Ю. Доценко, Є.А. Вилгіна. Проте досі не вирішеним залишається питання управління інноваційно-інвестиційним забезпеченням розвитку підприємств аграрного сектору на загальнодержавному та регіональному рівнях.

Формулювання цілей статті (постановка завдання). У науковій статті нами було поставлено завдання дослідити та узагальнити сучасні засади управління інноваційно-інвестиційним забезпеченням розвитку підприємств аграрного сектору на загальнодержавному та регіональному рівнях.

Виклад основного матеріалу дослідження 3 повним обгрунтуванням отриманих наукових результатів. Управління інвестиційною та інноваційною діяльністю стало найважливішою складовою частиною будь-якого сільськогосподарського підприємства, орієнтованого на стратегічний успіх у жорстких конкурентних умовах ринкової економіки. Таким чином, тісний взаємозв'язок інвестицій та інновацій на підприємстві не дає змогу розглядати ці процеси відокремлено один від одного, оскільки вони являють собою самостійну сферу економічної діяльності підприємства, пов'язану з фінансуванням та управлінням процесами оновлення всіх елементів функціонування суб'єктів господарювання в ринковій економіці [1, с. 159].

Однією 3 причин кризового стану агропромислового комплексу України є неефективна й недосконала система менеджменту на всіх рівнях управлінської вертикалі, тому виникає необхід- 
ність впровадження нових підходів до стратегії управління інноваційною діяльністю в АПК, бо саме за рахунок інноваційних перетворень аграрний бізнес України може мати конкурентні переваги на світовому ринку [2, с. 96].

Науковці визнають, що чинна система управління інноваційною діяльністю в галузі сільського господарства $є$ недосконалою та потребує змін. Зміни мають торкнутися як макроекономічних та нормотворчих аспектів інноваційно-інвестиційного розвитку галузі, так і мікроекономічних із застосуванням комплексного системного підходу до вирішення проблеми.

Система управління інноваційно-інвестиційним забезпеченням розвитку аграрних підприємств потребує розгляду в трьох вимірах, а саме на загальнодержавному рівні, на рівні регіону, в якому функціонує підприємство-новатор, та на рівні самого підприємства.

На загальнодержавному рівні, на нашу думку, нині потребує розроблення й впровадження в дію стратегія інноваційно-інвестиційного забезпечення розвитку аграрного сектору, яка у процесі іiі втілення передбачатиме величезну кількість стимулів для підприємств, які прагнуть до впровадження інновацій. Щоб запустити процес інноваційно-інвестиційного розвитку галузі, необхідні методи прямого дотування та непрямого стимулювання (наприклад, звільнення від оподаткування підприємств-новаторів), тобто необхідно, щоби були створені передумови для розвитку (рис. 1).

На рис. 1. зображені нині чинні передумови (зокрема, «Доступні кредити 5-7-9») й такі, що мають бути створені у процесі державного управління інноваційно-інвестиційним забезпеченням розвитку аграрних підприємств. Їх втілення в життя передусім пов'язане 3 необхідністю створення системи моніторингу інновацій, а також 3 необхідністю розроблення й впровадження електронної системи реєстрації підприємств-новаторів, які зможуть отримати консультаційну, юри- дичну та інші види інформаційної підтримки на всіх стадіях інноваційного процесу.

Крім того, зібрана інформація щодо підприємств-новаторів повинна застосовуватися для забезпечення державної підтримки інноваційних проєктів. Напрями такої підтримки зображені на рис. 1 та являють собою реальні передумови для інноваційно-інвестиційного розвитку аграрних підприємств. Впровадження цих передумов у життя разом зі збором інформації про підприємства-новатори дасть державі дієві важелі управління інноваційно-інвестиційним розвитком аграрного сектору.

Після того, як будуть створені передумови для стрімкого інноваційно-інвестиційного розвитку, необхідно на загальнодержавному рівні розробити стратегічні важелі управління (рис. 2), адже, як відомо, управляти можна лише тим, що існує, а нині інноваційний розвиток аграрних підприємств як масове явище не існує, тому розроблення стратегічних програм розвитку інновацій, яка здійснюється регулярно, не дає жодних вагомих результатів.

На нашу думку, стратегічні важелі управління інноваційно-інвестиційним розвитком мають включати як аспекти міжнародного співробітництва та інтеграції у світову торговельну систему, так і внутрішньодержавні заходи й регіональну інноваційну політику. Найбільш важливе місце відводиться напрямам загальної стабілізації економічної, валютно-фінансової і політичної ситуації в державі. Інвестиції люблять стабільність, а інновації - ще й передбачуваність ситуації. Аграрної галузі це твердження стосується ще більшою мірою, ніж інші галузі економіки.

На нашу думку, лише після того, як будуть створені першочергові передумови інноваційноінвестиційного розвитку та розроблені стратегічні важелі управління ним, можна переходити до формування загальної інноваційної політики аграрного сектору України.

В аграрній сфері слід виділити такі методи державної інноваційної політики:

\begin{tabular}{|c|c|c|c|}
\hline \multicolumn{4}{|c|}{ Передумови інноваційно-інвестиційного розвитку аграрних підприємств } \\
\hline \multicolumn{4}{|c|}{75} \\
\hline \multicolumn{2}{|c|}{$\begin{array}{c}\text { Податкові канікули - } \\
3 \text { роки з початку } \\
\text { впровадження інновацій }\end{array}$} & $\begin{array}{c}\text { Знижена ставка ПДВ } \\
\text { на інноваційну } \\
\text { продукцію }\end{array}$ & $\begin{array}{l}\text { Знижена ставка ЄСВ для } \\
\text { роботодавців, зайнятих } \\
\text { інноваційною діяльністю }\end{array}$ \\
\hline $\begin{array}{c}\text { Державні закупівлі } \\
\text { інноваційної } \\
\text { продукції }\end{array}$ & & $\begin{array}{l}\text { яме дотування інновацій, } \\
\text { моють соціальний та } \\
\text { екологічний ефект }\end{array}$ & $\begin{array}{c}\text { Державна програма } \\
\text { «Доступні кредити 5-7-9» }\end{array}$ \\
\hline
\end{tabular}

Рис. 1. Передумови інноваційно-інвестиційного розвитку аграрних підприємств Джерело: розроблено автором 
Стратегічні важелі управління інноваційно-інвестиційним розвитком

\begin{tabular}{|c|c|c|c|}
\hline \multicolumn{2}{|c|}{$\begin{array}{c}\text { Політична стабільність } \\
\text { та усталена нормативно- } \\
\text { законодавча база }\end{array}$} & $\begin{array}{l}\text { Стабільність курсу } \\
\text { національної } \\
\text { грошової одиниці }\end{array}$ & $\begin{array}{c}\text { Створення дієвої судової } \\
\text { системи для захисту інтересів } \\
\text { інвесторів та інноваторів }\end{array}$ \\
\hline $\begin{array}{c}\text { Розвиток зон вільної } \\
\text { торгівлі та повна } \\
\text { інтеграція з ЄС }\end{array}$ & & $\begin{array}{l}\text { Державні курс на } \\
\text { тортозаміщення і захист } \\
\text { iтчизняного виробника }\end{array}$ & $\begin{array}{c}\text { Урахування особливостей } \\
\text { розвитку регіонів та вдала } \\
\text { регіональна політика }\end{array}$ \\
\hline
\end{tabular}

Рис. 2. Стратегічні важелі управління інноваційно-інвестиційним забезпеченням розвитку аграрних підприсмств на загальнодержавному рівні

Джерело: розроблено автором

1)перенесення - використання наявного зарубіжного науково-технічного потенціалу в аграрній сфері шляхом закупівлі ліцензій на високоефективні технології для освоєння виробництва продукції;

2)запозичення - освоєння випуску наукоємної продукції, яку виробляли раніше в індустріально розвинутих країнах, на основі використання дешевої робочої сили та частини науково-технічного потенціалу аграрної сфери економіки;

3)нарощування - використання власного науково-технічного потенціалу, залучення іноземних учених, об'єднання досягнень фундаментальної і прикладної науки створювати нові продукти й технології, які використовуються у виробництві та соціальній сфері [3; 4].

В Україні усі три методи можуть бути реалізовані з великим успіхом, адже вітчизняні селекціонери та винахідники пропонують інновації, що не гірші від світових. Бракує лише їх масового впровадження в аграрному секторі, для чого, як ми уже зазначали, державою мають бути створені відповідні передумови, і певні кроки в цьому напрямі вже робляться.

Так, Постановою Уряду від 18 жовтня 2017 року затверджено середньострокові пріоритетні напрями інноваційної діяльності загальнодержавного рівня на 2017-2021 роки, серед яких задекларовані технологічне оновлення та розвиток агропромислового комплексу за такими напрямами, як розроблення та впровадження технологій виробництва, збереження i переробки високоякісної рослинницької продукції, технологій адаптивного грунтоохоронного землеробства, новітніх біотехнологій у рослинництві, тваринництві та ветеринарії, технологічне оновлення виробництва продукції скотарства та свинарства, розроблення та впровадження технологій створення високопродуктивних альтернативних джерел для отримання пального, технологій виробництва діагностикумів захворювань тварин і засобів ïх захисту, діагностик захворювань рослин [5].
Це дуже позитивний момент, що урядом декларуються такі важливі напрями розвитку аграрної науки й виробництва. Сподіваємося, що у найближчому майбутньому буде вжито дієвих заходів державного стимулювання інноваційного розвитку галузі.

Стосовно регіонального рівня управління інноваційним розвитком варто зазначити, що вагомим фактором виступає загальний індустріальний розвиток того чи іншого регіону та його інноваційна привабливість. Не останнє місце посідають чисельність навчальних закладів та наукових установ в регіоні, налаштованість місцевої влади на прогресивні технології та забезпечення вищого рівня інноваційно-інвестиційної привабливості регіону.

В контексті управління інноваціями доцільно розглянути рівень розвитку наукової та інноваційної діяльності регіону, щоб визначити, яке місце посідає Харківська область у загальному інноваційно-інвестиційному забезпеченні розвитку держави. Це дасть змогу дійти певних висновків щодо структури управління регіональним інноваційним розвитком та можливими напрямами його поліпшення.

Перш за все розглянемо прямі інвестиції в регіонах України (рис. 3). Розглядаючи прямі інвестиції в регіональному розрізі, перш за все маємо відзначити велику різницю обсягів інвестування в різних областях. Так, у економіку Дніпропетровської області інвесторами вкладено більше 3500 млн. дол. США, а в Чернівецьку область лише 44 млн. дол. США.

Харківська область у цьому рейтингу займає позицію області з обсягом інвестування вище від середнього, адже у 2018 році в економіку регіону було вкладено 666,4 млн. дол. США. Отже, область $€$ інвестиційно привабливим регіоном.

Інноваційні можливості області яскраво ілюструє інформація про чисельність працівників, зайнятих науковими дослідженнями (рис. 4). Можна дійти висновку, що Харківська область серед усіх областей має найвищий потенціал 


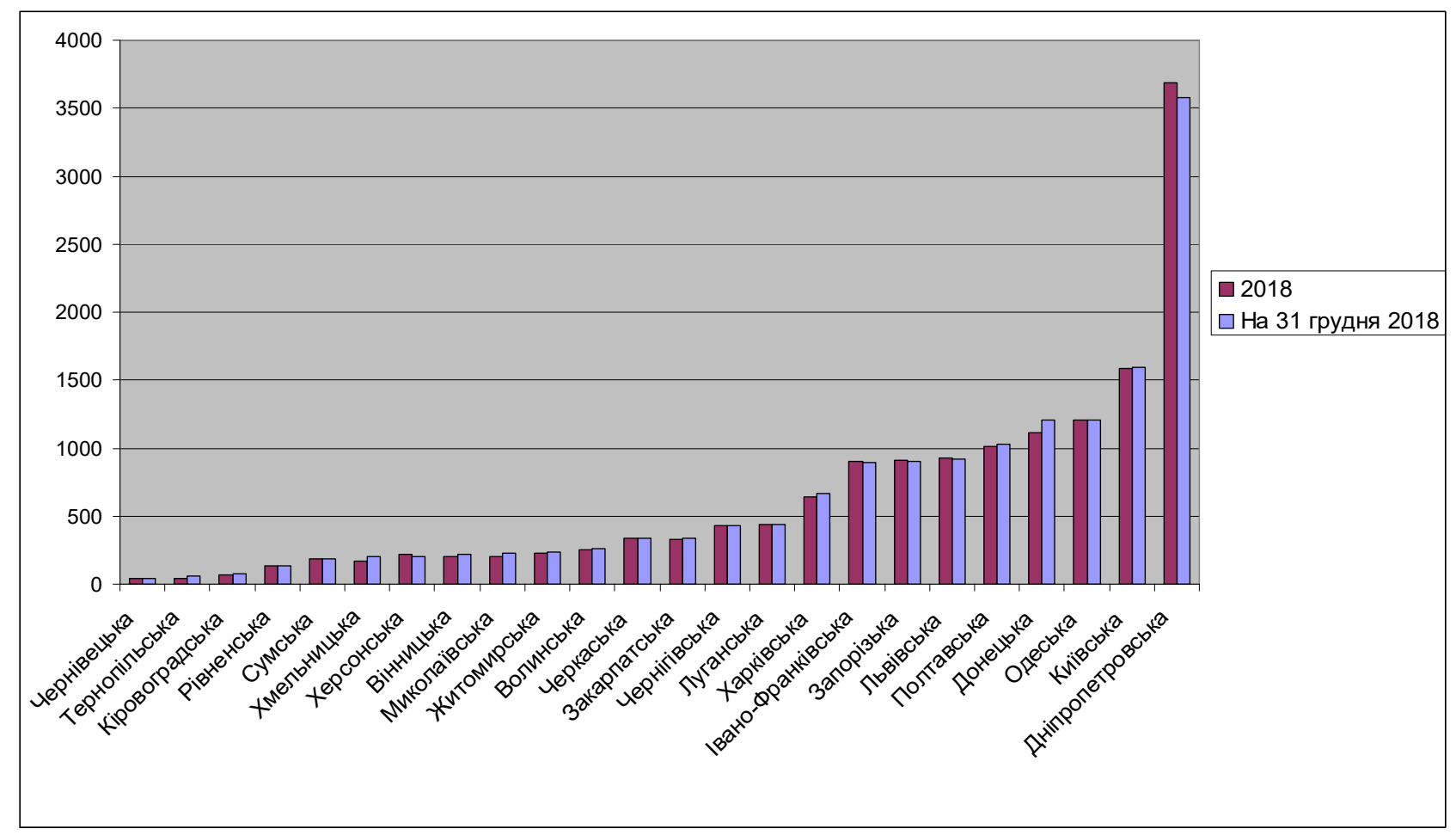

Рис. 3. Прямі інвестиції (акціонерний капітал) у регіонах України, млн. дол. США Джерело: побудовано автором на основі джерела [6]

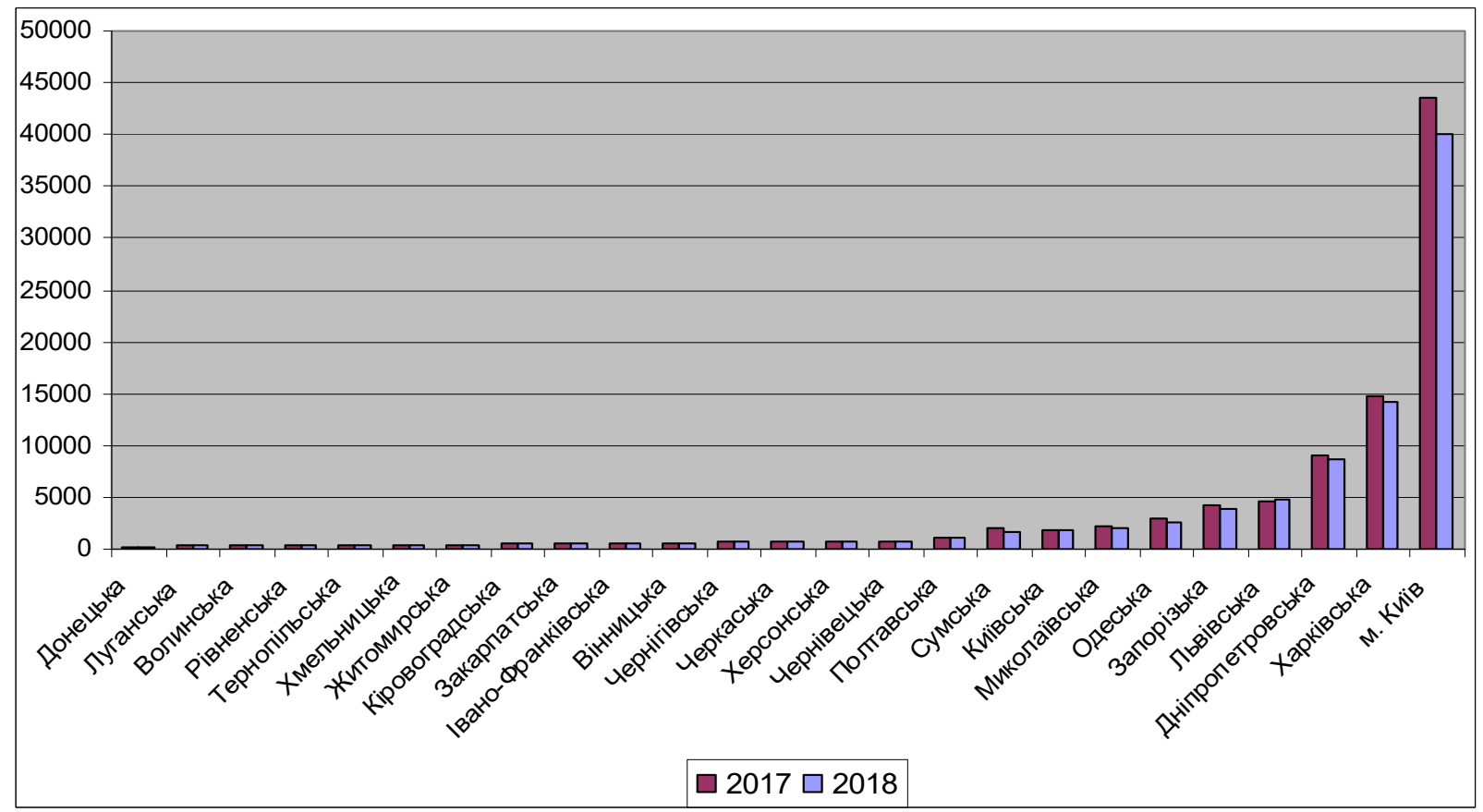

Рис. 4. Місце Харківської області за чисельністю працівників, зайнятих науковими дослідженнями і розробками

Джерело: побудовано автором на основі джерела [6]

наукових кадрів. Вищою чисельність наукових працівників є лише у м. Києві, тому інноваційні рішення, нестандартні підходи й нові принципи управління зароджуються саме тут, а знаходять своє втілення на всій території України. Станом на 2018 рік у Харківській області налічувалося 14226 наукових працівників, зокрема дослідників - 9528 осіб, техніків - 1493 осіб, допоміжного персоналу - 3205 осіб, які займалися дослідженнями у різних галузях наук. 
Розглянемо детальніше вікову структуру дослідників, які займалися НДДКР у Харківській області протягом 2016-2018 років, що дасть змогу дійти певних висновків про вік більшості науковців та їх сприйнятливість інноваційних ідей і проєктів (рис. 5). Отже, ми зможемо говорити про інноваційно-інвестиційний потенціал області та застосування тих чи інших методів управління інноваційним розвитком регіону.

Діаграма яскраво ілюструє «старіння» наукових кадрів, адже найбільшу категорію займають дослідники старше 60 років, чисельність яких протягом останніх років неухильно збільшується. Чисельність молодих науковців до 30 років, а також від 30 до 39 років за досліджуваний період зменшилась на $32,9 \%$ та 24,6\% відповідно. Кількість дослідників віком 40-49 та 50-59 років теж зменшилась, хоч і не так суттєво. Загалом по області у 2018 році працювало на 1852 осіб (на $16,3 \%$ ) менше, ніж у 2016 році.

Та ж тенденція спостерігається стосовно аграрних наукових кадрів. Чисельність дослідників скорочується, науковий потенціал галузі падає. Таким чином, триває криза аграрної науки, а підтримка держави для зміни ситуації на краще $\epsilon$ вкрай необхідною.

На нашу думку, управління інноваційно-інвестиційним розвитком регіону має базуватись на принципах масовості, результативності, адаптивності, інформаційної підтримки, фінансування, стимулювання (рис. 6).

Дотримання зазначених принципів уже саме по собі здатне активізувати підприємства до вкладання власних коштів в інновації та підвищення інтересу з боку інвесторів до сільськогосподарських підприємств регіону. Запровадження дієвого механізму управління інноваційним розвитком сільського господарства Харківської області разом із найбільшою серед областей України забезпеченістю науковими кадрами здатне здійснити прорив у виробництві наукоємної продукції в аграрному секторі регіону.

Процес інноваційного розвитку регіону припускає інтеграцію науково-технічної сфери в соціально-економічні процеси розвитку регіону, що передбачає формування системи інститутів, здатних генерувати нововведення й створювати нові ринки наукоємної продукції та послуг, у результаті чого формується регіональна інноваційна система [7, с. 34].

На цьому, зокрема, наголошує дослідник Є.А. Вилгін, який стверджує, що ефективна регіональна інноваційна політика повинна базуватись на об'єктивному аналізі господарської ситуації, детальному оцінюванні наявних ресурсів і можливостей, орієнтуванні на реальні, досяжні цілі. 3 огляду на важку економічну ситуацію в Україні загалом та в науково-виробничому секторі зокрема, відповідно, відсутність об'єктивних умов для повнокровного розгортання в регіонах інноваційних процесів під час розроблення регіональної інноваційної політики необхідно жорстко визначити першочергові цілі регіону в інноваційній сфері, що відповідають наявним можливостям [8].

Висновки із зазначених проблем i перспективи подальших досліджень у поданому напрямі. Дослідженням сучасних аспектів управління інноваційно-інвестиційним забезпеченням розвитку аграрних підприємств виявлено необхідність створення передумов для такого розвитку, що базуватимуться як на податкових (непрямих) методах, так і на прямих методах державного впливу й мають на меті активізувати інноваційні процеси в галузі на загальнодержавному рівні. Сформульовано стратегічні важелі управління інноваційно-інвестиційним розвитком регіону, які включають як внутрішньодержавні заходи стабі-

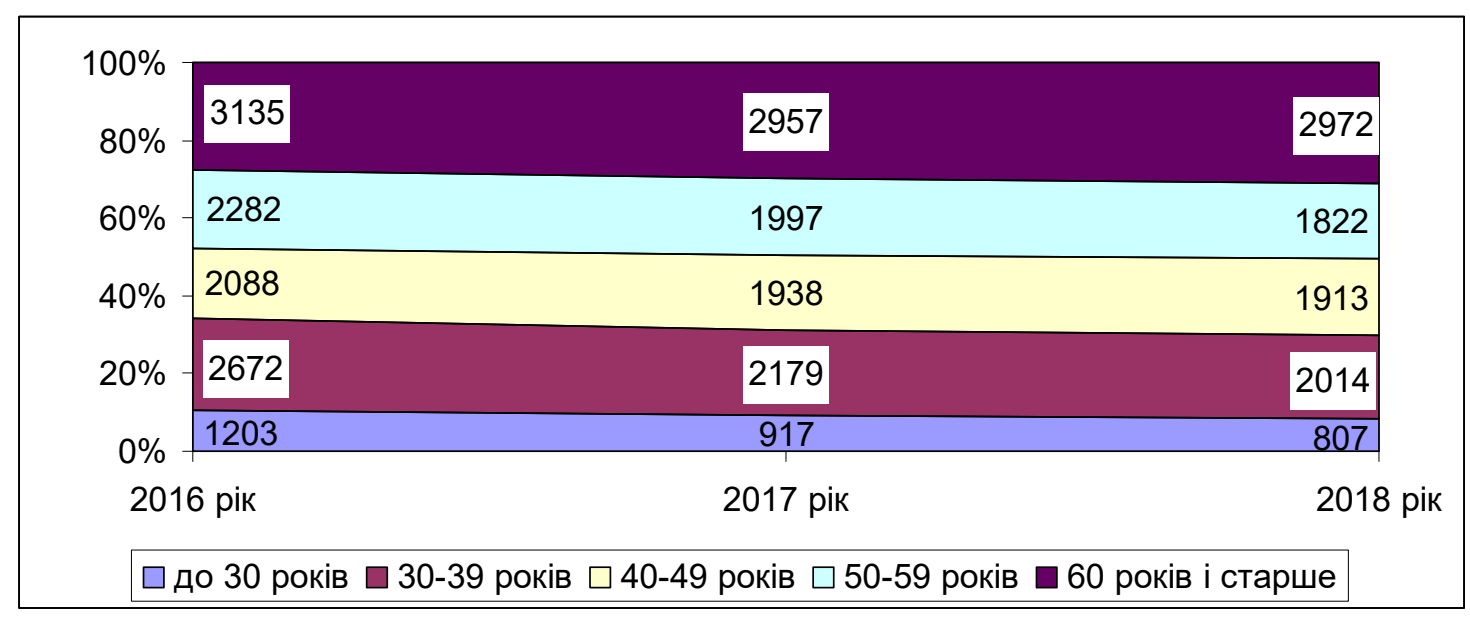

Рис. 5. Динаміка та структура кількості дослідників, задіяних у виконанні наукових досліджень і розробок, за віком у Харківській області

Джерело: побудовано автором на основі джерела [6] 


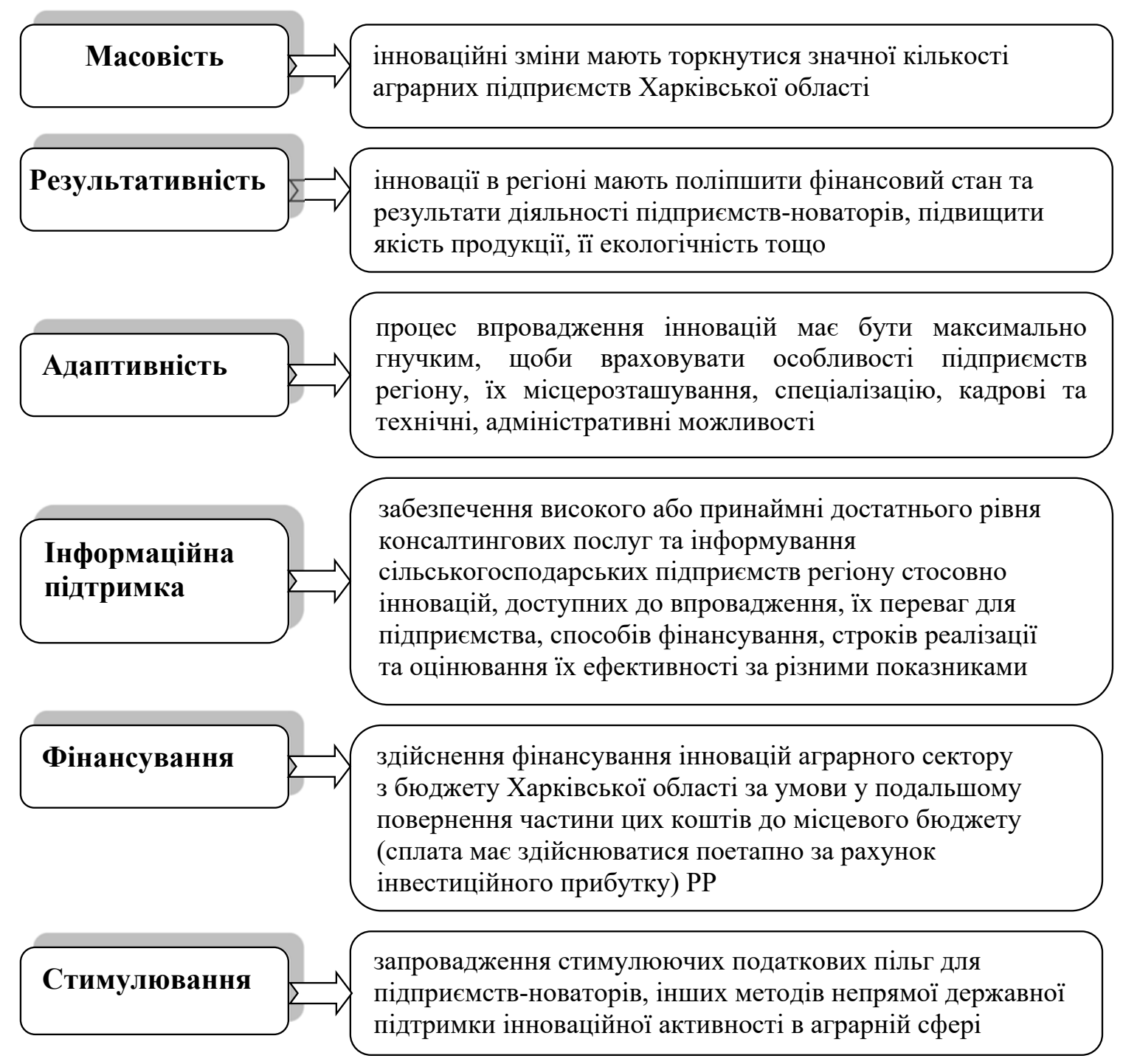

Рис. 6. Принципи управління інноваційно-інвестиційним розвитком регіону

Джерело: розроблено автором

лізації економіки, так і заходи міжнародного співробітництва та наукової інтеграції аграрної галузі для найбільш повного впровадження аграрних новацій у діяльності широкого кола вітчизняних сільськогосподарських підприємств.

Обгрунтовано, що під час формування та здійснення регіональної політики інноваційного розвитку необхідно враховувати специфічні особливості регіону, його переваги та слабкі сторони. Глибокий аналіз господарської ситуації, фінансових та технічних можливостей, спеціалізації регіону дасть змогу сформувати гнучку та адаптивну модель інноваційно-інвестиційного розвитку конкретного регіону та намітити стратегічні орієнтири й тактичні цілі. Сформовані нами напрями управління дадуть змогу активізувати інноваційно-інвестиційну діяльність на рівні регіону й забезпечать його стабільний інноваційно-інвестиційний розвиток, а це принесе високі економічні й фінансові результати діяльності та сприятиме розвитку аграрної галузі в регіоні зокрема та країні загалом.

Подальші дослідження нами будуть спрямовані на аналіз та узагальнення сучасних методів управління інноваційно-інвестиційним розвитком в аграрному секторі на рівні підприємства, а також пошук шляхів його поліпшення.

\section{СПИСОК ВИКОРИСТАНИХ ДЖЕРЕЛ}

1.Бойков В.О. Інноваційно-інвестиційний розвиток сільськогосподарських підприємств. Бізнес-навігатор. 2013. № 2. С. 159-165.

2. Чорна Н.В. Шляхи удосконалення інноваційно-інвестиційного забезпечення аграрного бізнесу в Україні. Наука молода. 2011. № 15-16. С. 95-100.

3. Корецький М.Х. Державне регулювання розвитку аграрної сфери економіки України : монографія. 2002.260 с. 
4. Васільєва Л.М. Формування інноваційно орієнтованої системи управління аграрним сектором в Україні. Публічне адміністрування: теорія та практика. 2011. № 2 (6). URL: http://www.dridu.dp.ua/zbirnik/2011-02(6)/11vl masu.pdf (дата звернення: 16.06.2021).

5.Деякі питання визначення середньострокових пріоритетних напрямів інноваційної діяльності галузевого рівня на 2017-2021 роки : Постанова Кабінету Міністрів України від 18 жовтня 2017 року № 980. URL: https://zakon.rada.gov.ua/laws/show/980-2017-\%D0\%BF\#n11 (дата звернення: 15.07.2021).

6. Статистичний збірник «Регіони України». Ч. 2 / за ред. І. Є. Вернера. Київ : Державна служба статистики України, 2018. 650 с.

7. Доценко О.Ю. Рівень інноваційного розвитку регіонів України та фактори, які його формують. Економічний вісник НГУ. 2010. № 4. С. 25-35.

8. Вилгін Є.А. Підходи до реалізації регіональної інноваційної політики держави. Державне управління: удосконалення та розвиток. 2011. № 4. URL: http://www.dy.nayka.com.ua/?op=1\&z=477 (дата звернення: 15.07.2021).

\section{REFERENCES}

1.Boikov V.O. (2013) Innovatsiino-investytsiinyi rozvytok silskohospodarskykh pidpryiemstv. Biznes-navihator, no. 2, pp. $159-165$.

2. Chorna N.V. (2011) Shliakhy udoskonalennia innovatsiino-investytsiinoho zabezpechennia ahrarnoho biznesu v Ukraini. Nauka moloda, no. 15-16, pp. 95-100.

3. Koretskyi M.Kh. (2002) Derzhavne rehuliuvannia rozvytku ahrarnoi sfery ekonomiky Ukrainy: monohrafiia, 260 p.

4. Vasilieva L.M. (2011) Formuvannia innovatsiino oriientovanoi systemy upravlinnia ahrarnym sektorom v Ukraini. Publichne administruvannia: teoriia ta praktyka, no. 2(6). Available at: http:/www.dridu.dp.ua/ zbirnik/2011-02(6)/11vlmasu.pdf (accessed 16 June 2021). (in Ukrainian)

5. Deiaki pytannia vyznachennia serednostrokovykh priorytetnykh napriamiv innovatsiinoi diialnosti haluzevoho rivnia na 2017-2021. Postanova Kabinetu Ministriv Ukrainy vid 18 zhovtnia 2017 roku, № 980. Available at: https://zakon.rada.gov.ua/laws/show/980-2017-\%D0\%BF\#n11 (accessed 15 July 2021). (in Ukrainian)

6. Statystychnyi zbirnyk "Rehiony Ukrainy". Ch. 2 / za redaktsiieiu I.Ye. Vernera. Derzhavna sluzhba statystyky Ukrainy. Kyiv. 2018. 650 p.

7. Dotsenko O.Iu. (2010) Riven innovatsiinoho rozvytku rehioniv Ukrainy ta faktory, yaki yoho formuiut. Ekonomichnyi visnyk $N H U$, no. 4, pp. 25-35.

8. Vylhin Ye.A. (2011) Pidkhody do realizatsii rehionalnoi innovatsiinoi polityky derzhavy. Derzhavne upravlinnia: udoskonalennia ta rozvytok, no. 4. Available at: http://www.dy.nayka.com.ua/?op=1\&z=477 (accessed 15 July 2021). (in Ukrainian)

И. А. Малыш, Харьковский национальный аграрный университет имени В.В. Докучаева. Управление инновационно-инвестиционным обеспечением развития предприятий аграрного сектора: общегосударственный и региональный аспект.

Аннотация. Цель статьи заключается в освещчении и обобщении современных основ управления инновационно-инвестиџионным обеспечением развития предприятий аграрного сектора на общегосударственном и региональном уровнях. Методика исследования. Решение поставленных в статье заданий осуществлено с помощьюю таких общенаучных и спещиальных методов исследования, как диалектический метод исследования экономических процессов и явлений, систематизация и обобщение научных подходов к решению проблемы, статистическое ранжирование регионов Украины по уровню их инновационного потенциала, а также методы анализа и синтеза, сравнения, индукиии и дедукции. Результаты. Разработан комплекс предпосылок для активизации инновационно-инвестиционного развития аграрного сектора страны и предложены стратегические рычаги управления инновационно-инвестиционным развитием. Разработан комплекс принцииов управления инновационно-инвестиционным развитием региона, таких как принциипы массовости, результативности, адаптивности, информационной поддержки, финансирования, стимулирования. Практическая значимость результатов исследования. В статье обосновано, что внедрение предложенных первоочередных предпосылок и стратегических ориентиров управления позволит сформировать гибкую и адаптивную модель инновационно-инвестиционного развития конкретного региона и будет способствовать высокотехнологичному современному ведению сельского хозяйства на инноваичионной основе.

Ключевые слова: инновационно-инвестиционное развитие, управление инновационно-инвестиционным развитием, стратегические направления управления, принципь управления инновационно-инвестиционным развитием, региональное развитие аграрного сектора.

Iryna Malysh, Kharkiv National Agrarian University named after V.V. Dokuchaev. Management of innovation and investment support for the development of enterprises in the agricultural sector: national and regional aspects.

Annotation. The purpose of the article is to highlight and summarize modern principles of management of innovation and investment support for the development of enterprises in the agricultural sector at the national and regional levels. Research methodology. The solution of the problems posed in the article was carried out using such general scientific and special research methods: the dialectical method of studying economic processes and phenomena, systematization and generalization of scientific approaches to solving the problem, statistical ranking 
of the regions of Ukraine by the level of their innovative potential, as well as the method of analysis and synthesis, comparison, induction and deduction. Results. A set of prerequisites for enhancing the innovation and investment development of the country's agricultural sector has been developed and strategic levers for managing innovation and investment development have been proposed. The level of development of scientific and innovative activity of the regions of Ukraine, in particular the place of Kharkov region, is investigated and it is revealed that foreign direct investments in Kharkov region are carried out at a high level, and the number of employees engaged in research and development is the largest. It is revealed that the potential of innovation and investment development of the agricultural sector of Kharkov region is high. The necessity of forming a regional innovation structure based on the integration of scientific and technical sphere into socio-economic processes of the region's development is substantiated. Based on this, proposals are made for further development of innovations in the agricultural sector and management of this process. A set of principles for managing the innovative and investment development of the region has been developed, namely: mass character, efficiency, adaptability, information support, financing, incentives. The practical significance of the research results. The article substantiates that the implementation of the proposed priority measures and strategic guidelines will allow to form a flexible and adaptive model of innovation and investment development of a particular region and will contribute to high-tech modern farming on an innovative basis.

Keywords: innovation and investment development, management of innovation and investment development, strategic directions of management, principles of management of innovation and investment development, regional development of the agricultural sector. 